\title{
A Research on the Determination of Income and Cost Elements Affecting the Capitalization Rate in Crop Lands: A Case Study of the Central District of Bayburt
}

\author{
Omer Kalyoncu (Corresponding author) \\ Yomra District Agriculture and Forestry Directorate, Trabzon, Turkey \\ E-mail: omer.kalyoncu@ tarimorman.gov.tr \\ https://orcid.org/0000-0003-1282-7622 \\ Avni Birinci \\ Atatürk University, Faculty of Agriculture, Erzurum, Turkey \\ E-mail: abirinci@atauni.edu.tr \\ https://orcid.org/0000-0003-0370-1454
}

\begin{abstract}
In order to appraise the field plots correctly, it is necessary to know the annual net income and costs and, accordingly, the capitalization rate that may apply to the property in question.

In this research, the factors affecting the capitalization rate for agricultural lands in the Central District of Bayburt Province are tried to be determined. Data obtained through face-to-face surveys from 80 agricultural enterprises in the region of the study were used. The data obtained cover the production year 2016 - 2017

According to the results obtained; The general average of gross product is $322.83 € / \mathrm{da}$. The general average of total expenses is $116.95 € / \mathrm{da}$, and their ratio in Gsh is $36.23 \%$. The average of the underwriter's capital interest provision is $10.33 € /$ and its ratio in Gsh is $3.20 \%$. The average of the remuneration for manual labor is $53,26 \mathrm{z} / \mathrm{da}$ and its ratio in Gsh is $18,70 \%$. The average of the tax expenses is $2.58 \mathrm{E} / \mathrm{da}$, and its rate in Gsh is $0.80 \%$. Among the lands, the highest income was determined in irrigated fields operated by the owner with 196,01 $₹ /$ da. The current sales value of the farm lands operated by the owner has been calculated as $2.986,31 € /$ da.
\end{abstract}

Keywords: Apprasial, land rant, income, cost, land value, capitalization rate

DOI: $10.7176 /$ JSTR/7-03-04

\section{Tarla Arazilerinde Kapitalizasyon Oranına Etki Eden Gelir Ve Maliyet Unsurlarının Tespiti Üzerine Bir Araştırma: Bayburt İli Merkez İlçe Örneği*}

\author{
* Çalışma Prof. Dr. Avni Birinci yönetimindeki Ömer Kalyoncu'ya ait Atatürk Üniversitesi Fen \\ Bilimleri Enstitüsü yüksek lisans tez (2018) çalışmasından türetilmiştir.
}

Özet

Tarla arazilerine doğru bir şekilde değer biçmek için yıllık net gelirlerinin ve masraflarının ve buna bağlı olarak söz konusu taşınmazda geçerli olabilecek kapitalizasyon oranının bilinmesi gerekmektedir. $\mathrm{Bu}$ araştırmada, Bayburt İli Merkez İlçedeki tarım arazileri için kapitalizasyon oranına etki eden faktörler tespit edilmeye çalışılmıştır. Araştırma yöresinde 80 tarım işletmesinden yüz yüze gerçekleştirilen anket çalışması yoluyla elde edilen veriler kullanılmıştır. Elde edilen veriler 2016 2017 üretim y1lı dönemini kapsamaktadır.

23 | P a g e

www.iiste.org 
Elde edilen sonuçlara gore; Gayrisafi hasılanın genel ortalaması 322,83 £/da'dır. Toplam masrafların genel ortalaması 116,95 €/da olup, Gsh içindeki oranı ise \%36,23’tür. Müstecir sermayesi faiz karşıllı̆ıııı ortalaması 10,33 ‡/da olup Gsh içindeki oranı \%3,20'dir. El emeği ücret karşılığının ortalaması 53,26 £/da olup Gsh içindeki oranı ise \%18,70'dir. Vergi masraflarının ortalaması 2,58 £/da olup Gsh içindeki oranı ise \%0,80'dir. Araziler arasında en yüksek rant 196,01 €/da ile mal sahibi tarafindan işletilen sulu tarla arazilerinde tespit edilmiştir. Mal sahibi tarafindan işletilen tarla arazilerinin cari satış değerleri ortalaması ise $2.986,31$ €/da olarak hesaplanmıştır.

Anahtar Kelimeler: Kıymet takdiri, arazi rantı, Gelir, masraf, arazi değeri, kapitalizasyon oranı

\section{GíRiş}

Tarım, hemen hemen her ülke için stratejik bir sektör konumundadır. Türkiye'de tarımda kullanılan arazilere değer biçme işlemi genellikle kamulaştırma amacıyla yapılmaktadır. Mevcut mevzuata göre kamulaştırma işlemleri 1983 tarih ve 2942 sayılı Kamulaştırma Kanunu ile bu kanunda değişiklik yapan 2001 tarih ve 4650 sayılı Kanunla yapilmaktadır (Anonim, 2002).

Özellikle büyük meblağlar gerektiren baraj, yol, toplu konut, sulama projeleri gibi yatırımların arazi değerleri ile yakın ilişkisi bulunmaktadır. Herhangi bir yatırıma karar verilirken güzergah üzerindeki arazilere ait fiyat düzeyinin yatırımları olumlu ya da olumsuz etkilemesi söz konusu olabilmektedir (Engindeniz vd., 2009). Her türlü arazi alım satımı, kredi alma ya da kredi verme, hasar tespiti ve zarar ziyan oranı tespiti, emlak ve tarımsal gelir vergisi belirlenmesi, miras paylaşımı, arazi toplulaştırması, irtifak hakkı tesisi ile doğaya ve tarıma verilen zararın tespiti için değer biçme kriter ve yöntemleri kullanılmaktadır (Mülayim, 2001).

Türkiye'de nüfusun yeterli ve dengeli beslenebilmesi için nüfus artışına paralel olarak tarımsal üretimin de arttırılması gerekmektedir. Tarımsal üretimi artırmanın yolu üretimin temel faktörü olan işlenen tarım alanlarının ve verimin artırılmasından geçmektedir. Nüfus artışı ve buna bağlı olarak artan ihtiyaçların karşılanabilmesi için doğal kaynaklar yetersiz kalmaktadır. Dolayısıyla tarımsal üretimin temel faktörlerinden olan toprak kaynağına olan talep geçen zaman içinde artmıştır. Çiftçilerin marjinal arazilerde üretim yapmaları tarımsal üretimde kullanılan arazinin son sınırına yaklaşıldığını ifade etmektedir (Birinci, 1993).

Özellikle son yıllarda Türkiye'de, baraj, toplu yerleşim, yol yapımı vb. yatırımlarda geniş ölçekli kamulaştırmalar yapılırken, tarıma yönelik yatırım politikaları açısından da ülke genelinde tarımsal arazi fiyatlarının bilinmesi ve izlenmesi gerekmektedir (Birinci, 1997).

Arazinin taşınmaz olması, üretimin sürekliliğinin ve arzının sınırlı olması, ekonomik bir üretim faktörü olarak da ona farklı bir özellik kazandırmakta ve değerinin belirlenmesinde izlenecek yol ve yöntemlerde diğer mal ve hizmetlere göre farkl1lık göstermektedir. Arazinin üniform bir ekonomik mal olmaması, bölgeden bölgeye, köyden köye, işletmeden işletmeye hatta parselden parsele değişik özellik ve değere sahip olması, arazi alım satımlarının çok sık olarak ortaya çıkmaması, pazarının iyi organize edilmiş pazar olmaması gibi özellikler, arazinin değerinin biçilmesini güçleştirmektedir (Aslan, 2002).

Tarımsal kıymet takdiri çalışmaları araştırmalarına bağlı olarak bölgesel yada lokal alanlarda yapılabilmektedir (Murray et al., 1969). Kapitalizasyon oranını etkileyen faktörler çok çeşitlidir ve bunlar bölgelere illere ve ilçelere göre farklılık göstermektedir.

Kapitalizasyon oranını etkileyen faktörler çok çeşitlidir ve bunlar bölgelere illere ve ilçelere göre farklılık göstermektedir. Bu durum göz önünde bulundurarak kapitalizasyon oranının her bölge için ayrı ayrı tespit edilmesi gerekmektedir (Mülayim ve ark., 1986).

Çalışmanın amacı Bayburt ili merkez ilçesi tarla arazilerine kıymet takdirinde kullanılabilecek kapitalizasyon oranına etki eden faktörleri tespit etmektir. Bu şekilde günümüz ve gelecekte bölgedeki tarla arazilerinin objektif kurallara göre değer takdiri yapılabilmesi için ilgililere hazır ve kullanılabilir bilgi sağlanabilecektir. Sigorta kavramı en genel ifadeyle; "bireylerin ve işletmelerin, gelecekte karşılaşabilecekleri olası risklerin olumsuz sonuçlarını ortadan kaldırmak ya da azaltmak amacıyla oluşturulmuş bir risk yönetim sistemi” şeklinde tanımlanabilir (Keskinkılıç 2013).

\section{MATERYAL ve YÖNTEM}

\subsection{Materyal}

Bayburt ili merkez ilçe tarım işletmelerinden anket yolu ile elde edilen veriler bu araştırmanın ana materyalini oluşturmaktadır. İşletme verilerinin temin edilebilmesi için Bayburt ili merkez ilçedeki 80 üreticiyle anket yapılmıştır. Veriler 2016-2017 üretim dönemine aittir. Önceden hazırlanmış olan anket

24 | P a g e

www.iiste.org 
formlarının uygulanması, üreticilerle yüz yüze ve tek tek görüşme ile araştırmacı tarafından EkimKasım 2017 döneminde gerçekleştirilmiş̧ir.

Araşıırma bölgesi için kullanılan genel ve tarımsal yapı hakkındaki bilgilerin hazırlanmasında Bayburt İl Tarım ve Orman Müdürlüğü, Bayburt Ziraat Odası Başkanlığı ile diğer kuruluşların kayıtları, yayınlanmamış rapor ve istatistikleri, ikincil veriler olarak kullanılmıştır.

\subsection{Yöntem}

\subsection{1. Örnekleme aşamasında uygulanan yöntem}

Araştırma yöresini temsil edebilecek 20 köy seçilmiştir. Köylerin seçiminde Gayeli Örnekleme Yöntemi kullanılmıştır. Araştırmaya konu köylerin büyüklükleri ve konumlarına göre 2 ile 5 arası işletme incelemeye alınarak toplam 80 işletme ankete tabi tutulmuştur. Bazı anketlerin uygun olmayabileceği düşünülerek, örnek büyüküğünün \%10'u kadar ( 8 adet) ilave anket yapılmıştır. 80 adet anket değerlendirmeye tabi tutulmuştur (Çiçek, A. ve Erkan, O. 1996).

\subsubsection{Anket aşamasında uygulanan yöntem}

Araştırma materyalinin toplanmasında kullanılan anket formlarının hazırlanmasında, Atatürk Üniversitesi Ziraat Fakültesi Tarım Ekonomisi Bölümünde daha önceki araştırmalarda kullanılan anket formları esas alınmış ve amaç doğrultusunda gerekli olan düzenlemelere gidilmiştir.

Verilerin üreticilerle yapılan yüz yüze görüşmeler sonucu elde edilmesi yoluna gidilmiştir. İşletme kayıtlarının tutulmaması ve üreticilerin sorulara hatalı cevap verebileceği düşünülerek, ankette kontrollü sorulara yer verilmiştir (Taraklı, 1979; Vural, 1987; Tanrıvermiş, 1996).

\subsubsection{Analiz aşamasında uygulanan yöntem}

İncelenen işletmelerin genel durumları, sahip oldukları nüfus, işgücü ve arazi durumları ile ilgili bilgiler ayrı ayrı belirlenmeye çalışılmıştır.

Anket yapılan işletmelerde üretim dönemleri ile ilgili gelir ve giderlere ait kayıtların tutulmadığı tespit edilmiştir. Bu nedenle üretici beyanları ile İl Tarım ve Orman Müdürlüğü ile Ziraat Odasından alınan 5 yıllık (2013-2017) verilerin ortalaması kullanılmıştır.

Gayrisafi hasıla (Gh): Ekonomik bir varlık olarak düşünülen tarım işletmelerinde bir tarımsal takvim yılı içerisinde üretilen ürünler veya bu ürünlerin işlenerek piyasaya sürülmesi sonucu elde edilecek mallardan elde edilecek hasıla ile değişim ve yeniden değerleme yolu ile sermayede oluşabilecek artışların miktar ve tutar olarak toplamları gayrisafi hasıla olarak tanımlanmaktadır (Gülten, 1975).

Münavebe sistemini oluşturan ürünlerin verim değerleri, normal bir tarım sisteminin uygulandığı varsayımı altında incelendiğinde doğruya yakın bir değer biçme işleminden söz edilebileceği ifade edilmektedir. Normal tarım sistemi uygulanması sonucunda elde edilecek karın sifir olduğu kabul edilmektedir (Mülayim, 2001).

Gayrisafi hasıla; arazi rantı ile üretim için yapılan amortisman, sigorta, tamir ve bakım masrafları; çiftlik dışından sağlanan tohum, yem ve gübre gibi girdiler ile dışarıdan temin edilen hizmetlerin parasal karşıllığı; işletme sermayesi faiz karşılığı; idare ücreti karşılığı; el emeği karşıllğı ve ödenen vergilerin toplamından oluşmaktadır.

İşletmelerde üretim sonucu elde edilen hasıladan $(\mathrm{H})$ üretim için tekrar işletmede kullanılanların (İk) çıkarılmasıyla miktar olarak bulunan değere cari fiyatların uygulanması sonucu da bulunabilecek olan gayrisafi hasıla değerinin tespitinde münavebe sistemi dikkate alınmalıdır. Bunun için değeri tespit edilmek istenen tarla arazisinin üzerinde yetiştirilen ürünlerin verimlerinin ve fiyatlarının belirlenmesi gerekmektedir.

Münavebe sistemine ait ürünlerin verim değerlerinin tespiti için eğer varsa muhasebe kayıtları kullanılabilmektedir. Güvenilir kimselerin vereceği bilgiler de kaynak olarak kullanılabilmektedir. Ancak kaynakların güvenirliliğinden emin olunmadığı durumlarda incelenen araziye ait geriye doğru 610 yıllık üretim toplamlarının aritmetik ortalaması alınabilir. Benzer şekilde arazilerin geriye doğru 610 yıllık üretim miktarlarından da yararlanılabilir. Geçmiş yıllarda elde edilen üretim miktarlarının aritmetik ortalaması alınırken dikkat edilmesi gereken nokta, gelecekte bir daha elde edilmesi zor olan uç seviyedeki üretim miktarlarının ortalamaya dahil edilmemesi gerektiğidir. Bu yollardan başka değer biçme uzmanının kişisel teknik bilgilerine dayanarak saptayacağı değerler de kullanılabilmektedir.

Hububat gibi önemli tarımsal ürünlerde pazar çok geniştir. İklim koşullarının üretim arzına etkisi, pazarın genişlemesi oranında azalmaktadır. Nitekim iklim koşulları bir bölgede kötü olursa, bir diğer bölgede iyi olabilir.

25 I P a g e

www.iiste.org 
O halde pazarın bugünkü koşullarına göre, arazinin satış fiyatının takdirinde amaca en uygun olarak izlenecek yol, o pazarda, o an için ileride oluşacağı varsayılan fiyatların alınmasıdır. Bunlar ülkenin gümrük ve para politikası, teknolojik durum, yiyecek alışkanlıkları, kalkınma planları, hükümet programları ve enflasyona göre ayarlanacak cari (bugünkü veya aktüel) fiyatlar olacaktır (Mülayim, 1994).

Üretim masrafları: Elde edilen gayrisafi hasıla değerleri bulunduktan sonra, gayrisafi hasıladan düşülecek çeşitli masraf unsurları vardır. Bu masraflar;

a) Çiftlik dışından sağlanan tohum, yem, tarım ilaçları gibi girdiler ile hizmet alım giderleri,

b) Genellikle belli bir oran üzerinden alınan sabit sermayelere ait amortisman, tamir ve bakım giderleri,

c) Hayvan, alet-makine ve döner işletme sermayelerinden oluşan işletme sermayesi faizi,

d) İdare ücret karşıllığ,

e) El emeği ücret karşılı̆̆

f) Arazi vergisi ve köye ait salma, koruma giderlerinden oluşmaktadır.

Bu masraf unsurlarının bazıları oranlar kullanılarak hesaplanmaktadır. Çünkü bir arazinin değeri tespit edilirken bazı faktörlerin değerinin somut olarak ifadesi zordur. Örneğin işletmenin yöneticiliği için ne kadar ücret ödenmesi gerektiği sübjektif bir nitelik göstermektedir. Bu yüzden idare ücret karşıllğının, gayrisafi hasılanın belli bir yüzdesi olarak alınması uygun bulunmaktadır (Aktaş, 2000).

Masraflar (M):Rantın hesaplanabilmesi için gayrisafi hasıladan çıkarılması gereken masraf kalemleri; a) Sabit sermayelerin amortisman, sigorta, tamir ve bakım masrafları: Genelde belli bir yüzde olarak alınırlar. Amortisman, bir sabit sermaye varlığının varsayılan ömrü boyunca her yıl masraf olarak kayıt edilmesi gereken yıpranma payıdır. Makine varlıkları için uygulamada genellikle 10 yıl ömür biçilmekte ve amortisman masrafı olarak her yıl makinenin yeni değerinin \%10'u alınmaktadır.

Sigorta ise, tarım işletmesinin üretime ait olası risklerini karşılama taahhüdünde bulunan kişiye ödediği primdir. Prim ödemenin şartı sigorta sözleşmesinin varlığıdır. Sigorta sözleşmesi varsa prim gerçektir. Uygulamada değer biçme yönünden sadece hayvan ve makine sermayesi ile ambardaki kuru otların sigortası hesaba katılmaktadır (Mülayim, 2001).

Alet makinelerin tamir ve bakım giderlerinin amortismanla yakın ilişsisi vardır. Tamir ve bakım masrafları arttıkça amortisman düşecektir. Bu yüzden amortisman ve tamir-bakım giderleri için beraber bir yüzde oranın tespit edilmesi uygun görülmektedir (Mülayim, 2001). Araştırmada amortisman, sigorta, tamir ve bakım masraflarının her üçü için küçük alet ve ekipman sermayesinin $\% 25^{\prime} \mathrm{i}$, motorlu makine ve ekipman sermayesinin \%10’u alınmıştır (Akay, 1996).

b) Döner işletme sermayelerinin tümden karşılanması: Döner işletme sermayesi masraf unsurları içinde tohumluk, gübre, ilaç ve su bedeli bulunmaktadır. Bu masraflardan tohum gübre ve ilaç miktarları ve değerleri anket esnasında çiftçilerin beyanları sonucu tespit edilmiştir. Su bedellerinin tespitinde arazilerin çoğu sulama birliğinin kanalları vasıtasıyla sulandığından sulama birliğinin tespit ettiği resmi fiyatlar dikkate alınmıştır.

c) Çiftlik dışından sağlanan hizmetlerin parasal karşılıkları: Bunların en önemlileri veteriner, ilaç, suni tohumlama, harman makinesi vb. hizmetlerdir. Yapılan araştırmada çiftliğin bütünü itibariyle değer tespiti yapılmayıp sadece tarla arazilerinin değer tespiti üzerinde çalışıldığından veteriner ve suni tohumlama masrafı dikkate alınmamıştır. İncelenen işletmelerde kullanılan alet ve makineler arazi sahiplerinin ise yapılan yakıt ve yağ masrafları hesaplanmış, dışarıdan temin edilmiş ise alet ve makine kirası kullanılmıştır.

Müstecir sermayesi faiz karşılığı (Mf): Müstecir sermayesi faiz karşılığı, tarımsal üretim yılı başlangıcında çiftlikte bulunması gereken müstecir sermayesi içim hesap edilen faizdir. Müstecir sermayesine "işletme sermayesi" de denilmektedir (Mülayim, 1994).

İşletme sermayesinin değeri tespit edildikten sonra faiz karşıllı̆ı hesaplanmaktadır. Bu sermayeye uygulanan faiz oranı, riski daha az olan kapitalizasyon oranından genellikle yüksektir. Bu yüzden tarımsal kredi faizleri kullanılabilmektedir. Ancak tarımsal kredi faizlerinin tam olarak uygulanması bilançoda işletme sermayesine daha fazla faiz ödeme riskini beraberinde getirdiğinden daha tutarlı olabilmesi için yarısının kullanılması uygun görülmektedir. Bu durum işletme sermayesinin hepsinin bir yıl süreyle işletmede kalmadığı varsayımına da uygun düşmektedir. Bunun için ortalama aylık bir sure kabul edilmiş ve hesaplamalar buna göre yapılmıştır (Mülayim, 2001).

26| P a g e

www.iiste.org 
İşletme sermayesi faiz karşılı̆̆ı, tarımsal üretim yılı başında çiftlikte bulundurulması gerekli olan hayvan, alet ve makine ile diğer döner işletme sermayesi unsurlarından oluşan sermaye grupları için ödenebilecek fiyatın faizidir.

İdare ücret karşılığı (İï): İdare ücret karşıllğı olarak genellikle gayrisafi hasılanın \%2'si ile \%7'si arasında bir oran alınmaktadır. Mal sahibi tarafindan işletilen işletmelerde \%3-7, ortakçılıkla işletilenlerde \%3-5 ve kiracılıkla işletilenlerde ise \%2-5 arasında bir oran alınmaktadır. Kiracılıkta oran kira üzerinden, ortakçılıkta ise gayrisafi hasıladan mal sahibine düsen pay üzerinden hesaplanmaktadır (Mülayim, 1994).

Bitkisel ürünlerin maliyet hesaplarında idare ücret karşıllı̆̆ olarak gayrisafi hasılanın \%3’u alınmaktadır (Açıl, 1977).

El emeği ücret karşılığı (Eü): Değer biçmeye konu olan arazinin bulunduğu yörede yabancı işçi çalışıırma, tarımsal faaliyetlerin işletmeci ve ailesi tarafından yerine getirilmesi ya da hem işletmeci ve ailesi hem de yabancı işçinin birlikte çalıștırılması geleneği söz konusu olabilir. El emeği ücretinin hesaplanması için başlıca üç yöntem kullanılabilmektedir. Değeri biçilen arazi mal sahibi tarafından işletilmekte ise, el emeği ücret karşılı̆̆ı şu yollara göre bulunmaktadır.

a) Bölgede iş sözleşmeleri geleneği var ise bu sözleşmelerden yararlanılabilir. Araziye gerekli işgücü miktarı tespit edilerek yörede geçerli iş̧̧ ücretleri ortalamalarıyla çarpılarak yıllık el emeği ücreti hesaplanabilmektedir.

b) Eğer değeri biçilen arazinin bulunduğu bölgede küçük köylü mülk işletmeleri egemen ise, bir başka ifade ile yabancı işçi çalıştırılmıyor ise, o zaman el emeği ücret karşılı̆ıının hesaplanmasında Formül 3.1. kullanılmaktadır.

c) Her bölgede ortalama olarak el emeği ücret karşıllğının gayrisafi hasıla içindeki belli bir yüzdesi bulunur. Bulunan bu yüzdeler uygulanarak da el emeği ücret karşılığı hesaplanabilmektedir (Mülayim, 1994).

Vergiler (V): Devlete mal sahibi tarafindan ödenen arazi vergisi ile il veya köylerde ödenen diğer vergilerden oluşmaktadır (Mülayim, 2008).

Tarım arazisinin vergilendirilmesi, Türkiye sınırları içerisinde bulunan arsa ve araziler Emlak Vergisi Kanunu'na (EVK) göre arazi vergisinin konusunu oluşturmaktadır. Dolayısıyla belediye ve mücavir alan sınırları içerisinde bulunan arazi, arazi vergisinin konusu içerisinde bulunmaktadır (Hayran, 2013). İncelenen işletmelerde vergi masrafları, ilgili belediyeye ödenen arazi vergisi ile Çiftçi Malları Koruma Başkanlığı'na ödenen koruma ve sulama ücretlerinden oluşmaktadır.

Arazi rantları (R): Rant, gayrisafi hasıladan, arazi kirası ve sermayenin faizi hariç, üretim için gerekli olan diğer bütün masrafların çıkartılması sonucu hesaplanan net gelirdir (Aydın ve Akay, 2008).

Başka bir tanımlamada da rant, toprak üzerindeki özel mülkiyeti nedeniyle toprak sahibince alınan bir bedeldir. Bir başka deyişle, insan emeğinin ürünlerini kullanmak için değil de, doğrudan doğal varlıkların kullanılabilmesi için ödenen bir bedeldir (Ökmen ve Yurtseven, 2010).

Rant geniş anlamda, arazi ve bina gibi taşınmazlarla ilgili kiradır. Ekonomide ise rant, üretim faktörlerinin birisi olan toprağın kullanılması karşıllı̆ında elde edilen geliri göstermektedir. Rant, esasen toprağın kıt olması ve toprak arzının inelastik olması nedeniyle ortaya çıkmaktadır. Bu açıdan meydana gelen ranta mutlak rant denilmektedir (Karagölge, 1996).

Arazilerin ve arsaların alım satım bedelleri üzerinden vergi alındığı için Tapu Sicil Müdürlüklerinde kayıtlı alım-satım bedelleri gerçek alım satım bedellerini yansıtmamakta ve gerçek değerlerinin altında işlem görmektedir. Bu nedenle kapitalizasyon oranın hesaplanmasında kullanılacak olan arazi alım satım değerlerinin belirlenmesinde; alım veya satım gerçekleştirmiş kişilerle, araştırma bölgesinde konu hakkında bilgi sahibi olan yerel uzmanlarla ve mahalle/köy bilirkişileriyle görüşülmüștür. Ayrıca, emlak ofisleri, Belediyeler ve Ziraat Odalarından değerlemeye yardımcı olacak bilgiler ve arazilerin rayiç bedelleri hakkında veriler alınmıştır.

İncelenen işletmelerdeki tarla arazilerinin 2017 yılındaki cari satış fiyatları; arazi sahipleri, bölgeyi iyi tanıyan kişiler, İl Tarım ve Orman Müdürlüğü elemanları, emlakçılar, çeşitli komisyoncular, Tapu ve Kadastro Müdürlüğü elemanlarıyla görüşülüp, kıymeti etkileyen çeşitli faktörler de dikkate alınmıştır.

27 I P a g e

www.iiste.org 
$\mathrm{Bu}$ amaçla tarla arazilerinin işletilme (mal sahibi-ortakçı-kiracı) ve sulama (sulu-kuru) durumlarına göre ayrı ayrı rantları tespit edilerek, mal sahibi tarafından işletilen araziler için sulu-kuru ve ortalama kapitalizasyon oranları hesaplanmıştır. Aynı işlemler kiracılık ve ortakçılıkla işletilen araziler için de uygulanmıştır.

\section{ARASTIRMA BULGULARI}

\section{Uygulanan münavebe sistemleri}

Bir tarım arazisinde en uygun verimlilik ve üretim düzeyinin sağlanması için iklim koşullarının elverdiği ölçüde yörenin bitkisel üretim desenine uygun çeşit ve türlerin, belli bir sırada tarımsal üretim zamanlarına dağılımı ile uygulanmasına münavebe sistemi denilmektedir.

Münavebedeki bitki seçimi ve sıralamasında öncelikle iklim faktörü önemli olmakla birlikte çiftçilerin tercih ve alışkanlıkları, ürün fiyatları ya da girdi fiyatları gibi faktörler de etken olmaktadır.

Araştırma sonuçlarına göre incelenen işletmelerdeki tarla arazilerinde belirlenen münavebe sistemleri Çizelge 1'de verilmiştir.

Çizelge 1. İncelenen tarla arazilerinde belirlenen münavebe sistemleri

\begin{tabular}{ll}
\hline \multicolumn{1}{c}{ Arazi Nev'i } & \multicolumn{1}{c}{ Belirlenen Münavebe Sistemleri } \\
\hline Sulu Tarla Arazisi & Hububat - Yem Bitkisi - Hububat \\
\hline Kuru Tarla Arazisi & Hububat - Yem Bitkisi - Nadas \\
& Hububat - Yem Bitkisi - Hububat - Nadas \\
\hline
\end{tabular}

\subsection{Gayrisafi hasila (Gh)}

İşletmelerin verim durumları hesaplanırken; sulu ve kuru şartlarda yetiştirilme durumları da dikkate alınarak veriler toplanmıştır. Bayburt Ziraat Odası ile Bayburt İl Tarım ve Orman Müdürlüğünden alınan verilerle de karşılaş̧ırılarak 2017 yılı dahil son 5 (beş) yılın ortalaması alınmıştır.

Araştırmada ürün fiyatları tespit edilirken; pazarda tüketicilere veya hal işletmelerinde komisyonculara satılma durumuna göre satış fiyatları, herhangi bir resmi kuruma satılma durumuna göre resmi fiyatlar ile Bayburt İl Tarım ve Orman Müdürlüğü verileriyle de karşılaş̧ırılarak ortalaması alınıştır.

Ürünlerin ortalama verim durumları ve 2017 yılına ait ürünlerin ortalama fiyatları göz önünde bulundurularak gayrisafi hasıla değerleri hesaplanmıştır.

İncelenen işletmelerden, mal sahibi tarafindan işletilen sulu arazilerin gayrisafi hasılalarına ait değerler Çizelge 2'de, mal sahibi tarafından işletilen kuru arazilerin gayrisafi hasılalarına ait değerler ise Çizelge 3'te verilmişsir.

Çizelge 2. Mal sahibi tarafından işletilen sulu tarla arazilerinin gayrisafi hasıla değerleri

\begin{tabular}{lr}
\hline Ürünler & Gayrisafi Hasıla (†/da) \\
\hline Arpa & 465,11 \\
Buğday & 568,64 \\
K.Fasulye & $1.695,62$ \\
Fĭg (Dane) & 584,51 \\
Fiğ & 427,50 \\
Korunga & 340,00 \\
Misır (Silaj) & $1.045,00$ \\
Patates & $2.061,00$ \\
Yonca & 400,00 \\
Yulaf & 400,00 \\
\hline TOPLAM & $\mathbf{6 2 4 , 4 0}$ \\
\hline
\end{tabular}

Mal sahibi tarafindan işletilen arazilerin toplam gayrisafi hasıla değerlerine €/da bazında bakıldığında bu değer, suluda 624,40 €/da ve kuruda ise 304,36 €/da olarak bulunmuştur. Dekara ortalama gayrisafi hasıla ise 468,95 £ olarak hesaplanmıştır. 
Çizelge 3. Mal sahibi tarafından işletilen kuru tarla arazilerinin gayrisafi hasıla değerleri

\begin{tabular}{lc}
\hline Ürünler & Gayrisafi Hasıla (‡/da) \\
\hline Arpa & 340,25 \\
Buğday & 373,85 \\
Çavdar & 337,50 \\
Çayır & 137,50 \\
Fĭ̆ & 285,00 \\
Korunga & 255,00 \\
Mercimek & 825,00 \\
Tritikale & 369,85 \\
Yonca & 280,00 \\
Yulaf & 300,00 \\
\hline TOPLAM & $\mathbf{3 0 4 , 3 6}$ \\
\hline
\end{tabular}

İncelenen işletmelerden, ortakçılıkla işletilen sulu arazilerin gayrisafi hasılalarına ait değerler Çizelge 4 'te, ortakçılıkla işletilen kuru arazilerin gayrisafi hasılalarına ait değerler ise Çizelge 5'te verilmiştir.

Çizelge 4. Ortakçılıkla işletilen sulu tarla arazilerinde gayrisafi hasıla değerleri

\begin{tabular}{cc}
\hline Ürünler & Gayrisafi Hasıla (‡/da) \\
\hline Buğday & 578,50 \\
Fĭg & 427,50 \\
Korunga & 340,00 \\
Misır (Silaj) & $1.045,00$ \\
Yonca & 400,00 \\
\hline TOPLAM & $\mathbf{5 7 3 , 9 4}$ \\
\hline Mal Sahibine Düşen & $\mathbf{2 8 6 , 9 7}$ \\
\hline
\end{tabular}

Çizelge 5. Ortakçılıkla işletilen kuru tarla arazilerinde gayrisafi hasıla değerleri

\begin{tabular}{cc}
\hline Ürünler & Gayrisafi Hasıla (‡/da) \\
\hline Buğday & 384,36 \\
Fĭg & 285,00 \\
Korunga & 255,00 \\
Tritikale & 394,19 \\
Yonca & 280,00 \\
\hline TOPLAM & $\mathbf{3 2 8 , 7 2}$ \\
\hline Mal Sahibine Düșen & $\mathbf{1 6 4 , 3 6}$ \\
\hline
\end{tabular}

Araştırma bölgesinde ortakçılıkta, üretimle ilgili her türlü gelir ve giderlerin paylaşımı yarı yarıyadır. Ortakçılıkla işletilen sulu ve kuru tarım arazilerine ait toplam gayrisafi hasıla değerleri $¥ /$ da bazında suluda 286,97 €/da, kuruda 164,36 છ/da ve ortalama gayrisafi hasıla değeri ise 225,87 €/da olarak hesaplanmıştır.

İncelenen işletmelerden, kiracılıkla işletilen sulu ve kuru arazilerin gayrisafi hasılalarına ait değerler Çizelge 6'da verilmiştir.

Çizelge 6. Kiracılıkla işletilen tarla arazilerinde gayrisafi hasıla değerleri

\begin{tabular}{lccc}
\hline & $\begin{array}{c}\text { Kiraya Verilen } \\
\text { Alan (da) }\end{array}$ & $\begin{array}{c}\text { Ayni veya Nakdi Kira Bedelleri } \\
\text { Toplamı }(\text { Gsh) }(\mathbf{(})\end{array}$ & $\begin{array}{c}\text { Gayrisafi Hasıla } \\
(\mathbf{f} / \mathbf{d a})\end{array}$ \\
\hline Sulu & 357 & $28.170,87$ & 78,91 \\
Kuru & 534 & $26.532,78$ & 49,67 \\
Ortalama & $\mathbf{5 9 , 4}$ & $\mathbf{3 . 6 4 6 , 9 1}$ & $\mathbf{6 1 , 3 9}$ \\
\hline
\end{tabular}


Kiracılıkla işletilen sulu ve kuru tarım arazilerine ait toplam gayrisafi hasıla değerleri suluda 28.170,87 €, kuruda 26.532,78 € olarak hesaplanmıştır. Kiracıllkla işletilen sulu ve kuru tarım arazilerine ait toplam gayrisafi hasıla değerleri §/da bazında, suluda 78,91 £/da, kuruda 49,67 £/da ve ortalama 61,39 ६/da olarak tespit edilmiştir.

Araştırma bölgesinde toplam gayrisafi hasıla değerlerinin €/da ortalaması suluda 465,47 £/da, kuruda ise 198,32 €/da olarak belirlenmiştir. Gayrisafi hasılanın genel ortalaması ise $322,83 \varsubsetneqq / \mathrm{da}$ ’ $\mathrm{d} ı$.

\section{2. Üretim masrafları}

Mal sahibi tarafindan işletilen tarla arazilerine ait masraf kalemleri ve değerleri Çizelge 7'de, ortakçıllkla işletilenlerin değerleri ise Çizelge 8 'de verilmiştir.

Çizelge 7. Mal sahibi tarafından işletilen arazilere ait masraflar

\begin{tabular}{lccc}
\hline & Sulu & Kuru & Ortalama \\
\hline $\begin{array}{l}\text { Sabit Sermayeleri Amortisman, Sigorta, Tamir ve Bakım } \\
\text { Masrafları (€) (1) }\end{array}$ & 61,34 & 41,36 & 51,08 \\
$\begin{array}{l}\text { Döner İşletme Sermayelerinin Tümden Karşılanması (£) } \\
\text { (2) }\end{array}$ & 108,75 & 39,53 & 72,59 \\
$\begin{array}{l}\text { Ciftlik Dışından Sağlanan Hizmetlerin Parasal Karşıllı̆ı (£) } \\
\text { (3) }\end{array}$ & 72,98 & 40,54 & 56,17 \\
\hline TOPLAM MASRAFLAR (†) (M) (1+2+3) & $\mathbf{2 4 3 , 0 7}$ & $\mathbf{1 2 1 , 4 3}$ & $\mathbf{1 7 9 , 8 4}$ \\
\hline Masrafların Gsh İçindeki Oranı (\%) & 38,93 & 39,90 & 38,35 \\
\hline
\end{tabular}

Mal sahibi tarafindan işletilen arazilere ait masraflar suluda 243,07 Æ/da olup Gsh içindeki oranı $\% 38,93$ 'tür. Bu masraflar kuruda 121,43 £/da, Gsh içindeki oranı ise \%39,90'dır. Ortalama masraflar ise 179,84 £/da olup Gsh içindeki oranı $\% 38,35$ ’tir.

Çizelge 8. Ortakçılıkla işletilen arazilerde belirlenen masraflar

\begin{tabular}{|c|c|c|c|}
\hline & Sulu & Kuru & Ortalama \\
\hline $\begin{array}{l}\text { Sabit Sermayeleri Amortisman, Sigorta, Tamir ve Bakım } \\
\text { Masrafları (£) (1) }\end{array}$ & 34,23 & 20,18 & 27,23 \\
\hline $\begin{array}{l}\text { Döner İşletme Sermayelerinin Tümden Karşılanması (‡) } \\
\text { (2) }\end{array}$ & 46,43 & 30,81 & 38,65 \\
\hline $\begin{array}{l}\text { Çiftlik Dışından Sağlanan Hizmetlerin Parasal Karşılı̆̆ } \\
(€)(3)\end{array}$ & 46,39 & 34,38 & 40,40 \\
\hline TOPLAM MASRAFLAR (†) $(\mathrm{M})(1+2+3)$ & 127,05 & 85,37 & 106,28 \\
\hline Masrafların Gsh İçindeki Oranı (\%) & 44,27 & 51,94 & 47,05 \\
\hline
\end{tabular}

Ortakçılık işletmelerinde belirlenen masraflar suluda 127,05€/da olup, Gsh içindeki oranı \%44,27'dir. Kuruda bu masraf 85,37 £/da olup Gsh içindeki oranı ise \%51,94'tür. Ortalama masraf 106,28 £/da olup, Gsh içindeki oranı $\% 47,05$ 'tir.

Araş̧ırma bölgesinde toplam masraf değerleri suluda ortalama 180,43 ‡/da olup Gsh içindeki oranı $\% 38,76$ 'dır. Kuruda ise bu rakam 61,53 ₹/da olarak hesaplanmıştır. Gsh içindeki oranı ise \%31,03’tür. Toplam masrafların genel ortalaması 116,95 £/da olup, Gsh içindeki oranı ise \%36,23 olarak hesaplanmıştır.

\subsubsection{Müstecir sermayesi faiz karşılığı (Mf)}

İncelenen işletmelerde müstecir sermayesi faiz hesaplamasında dikkate alınacak, alet ve makine sermayesi ile ambar mevcudu bulunmaktadır. Üretimde alet ve makine kullanımı yaygın olup iş hayvanı ve kasa mevcuduna rastlanılmamıştır. İncelenen işletmelerde ortalama olarak belirlenen müstecir sermayesi faiz karşılıkları Çizelge 9'da verilmiş̧ir. 
Çizelge 9. İşletmelerde belirlenen müstecir sermayesi faiz karşılı̆̆g

\begin{tabular}{lcc}
\hline & $\begin{array}{c}\text { Müstecir Sermayesi Faiz Karşılı̆̆ } \\
\text { (Mf) (t) }\end{array}$ & Gsh İçerisindeki Oranı (\%) \\
\hline Mal Sahibi Sulu & 17,55 & 2,81 \\
Mal Sahibi Kuru & 11,84 & 3,89 \\
Ortalama & $\mathbf{1 4 , 4 9}$ & $\mathbf{3 , 0 9}$ \\
\hline Ortakçılık Sulu & 8,29 & 2,89 \\
Ortakçlık Kuru & 5,85 & 3,56 \\
Ortalama & $\mathbf{6 , 8 9}$ & $\mathbf{3 , 0 5}$ \\
\hline
\end{tabular}

* Müstecir Sermayesi Faizi hesaplanmasında \%2 faiz oranı kullanılmıştır.

Mal sahibi tarafından işletilen arazilerde belirlenen müstecir sermayesi faiz karşılığ suluda 17,55£/da olup Gsh içindeki oranı \%2,81'dir. Kuruda bu değer 11,84€/da, Gsh içindeki oranı ise \%3,89'dur. Ortalama müstecir sermayesi faiz karşılığı 14,49£/da olarak hesaplanmış olup, Gsh içindeki oranı $\% 3,09$ 'dur.

Ortakçılıkla işletilen arazilerde belirlenen müstecir sermayesi faiz karşılığı suluda 8,29€/da, Gsh içindeki oranı ise \%2,89'dur. Kuruda bu değer 8,85€/da olup Gsh içindeki oranı \%3,56'dır. Ortalama müstecir sermayesi faiz karşılığ da 6,89æ/da olarak belirlenmiş olup, Gsh içindeki oranı \%3,05’e tekabül etmektedir.

Araştırma bölgesinde toplam müstecir sermayesi faiz karşılığı suluda ortalama 12,82 £/da olup Gsh içindeki oranı \%2,75'tir. Kuruda ise bu rakam 8,38 €/da olup Gsh içindeki oranı \%4,23’tür. Toplam müstecir sermayesi faiz karşılığının ortalaması 10,33 £/da olup Gsh içindeki oranı \%3,20 olarak hesaplanmıştır.

\subsection{2. İdare ücret karşılı̆̆ı (İü)}

İncelenen işletmelere ait idare ücret karşılıkları hesaplanırken kullanılan rakamlar Çizelge 10'de verilmiştir.

Çizelge 10. İşletmelerde belirlenen idare ücret karşılığ1

\begin{tabular}{|c|c|c|c|}
\hline & $\begin{array}{l}\text { İdare Ücret } \\
\text { Karşılığı (İ̈̈) } \\
\text { (Đ)/da) }\end{array}$ & $\begin{array}{c}\text { İ̈̈’nün Gsh } \\
\text { İçerisindeki Oranı } \\
(\%)\end{array}$ & $\begin{array}{c}\text { İü’nün Kira Bedeli } \\
\text { İçerisindeki Oranı }(\%)\end{array}$ \\
\hline Mal Sahibi Sulu & 31,22 & 5,00 & - \\
\hline Mal Sahibi Kuru & 15,22 & 5,00 & - \\
\hline Ortalama & 23,44 & 5,00 & - \\
\hline Ortak Sulu & 11,48 & 4,00 & - \\
\hline Ortak Kuru & 6,57 & 4,00 & - \\
\hline Ortalama & 9,03 & 4,00 & - \\
\hline Kira Sulu & 2,37 & - & 3,00 \\
\hline Kira Kuru & 1,49 & - & 3,00 \\
\hline Ortalama & 1,84 & - & 3,00 \\
\hline
\end{tabular}

Mal sahibi tarafından işletilen arazilerde belirlenen idare ücret karşılığı suluda 31,22 ‡/da, kuruda 15,22 モ/da olup ortalama idare ücret karşılığı 23,44 છ/da'dır. Mal sahibi tarafından işletilen arazilerde belirlenen idare ücret karşılığının Gsh içindeki oranı \%5'tir.

Ortakçılıkla işletilen arazilerde belirlenen idare ücret karşılığı suluda 11,84 છ/da, kuruda 6,57 €/da olup ortalama idare ücret karşılığ 19,03 છ/da'dır. Ortakçılıkla işletilen arazilerde belirlenen idare ücret karşılığının Gsh içindeki oranı ise \%4 olarak tespit edilmiştir.

Kiracılıkla işletilen arazilerde belirlenen idare ücret karşılığı suluda 2,37£/da, kuruda 1,49£/da olup ortalama idare ücret karşılığı 1,84€/da'dır. İdare ücret karşılığının kira bedeli içindeki oranı ise \%3’tür. Araştırma bölgesinde toplam idare ücret karşılığı suluda ortalama 22,36 ‡/da olup Gsh içindeki oranı \%4,80'dir. Kuruda 10,85 €/da olup Gsh içindeki oranı \%5,47'dir. İdare ücret karşılığının ortalaması 16,54 €/da olarak hesaplanmış olup, Gsh içindeki oranı ise \%5,12 olarak hesaplanmıştır. 


\subsubsection{El emeği ücret karşılığı (Eü)}

Anketlerle elde edilen veriler ışığında yörede üretim dallarına ilişkin iş gücü ihtiyaçları belirlenmiştir. Belirlenen bu işgücü ihtiyaçlarının yabancı bir erkek isçiye ödenen günlük ücret ile çarpılması sonucu da el emeği ücret karşılığı tespit edilmiş̧ir. Araştırma bölgesinde, tarımsal işlerde çalışan yabancı erkek iş̧̧ilere ödenen günlük yevmiye işin türüne göre farkl1lık göstermekte olup ortalama 90.00 £'dir. Aile işgücü ücret karşıllı̆ının hesaplanmasında işletme yöneticilerinin görüşlerine başvurulmuştur. Yapılan işlemler sonucu, incelenen işletmelerde ortalama olarak belirlenen el emeği ücret karşıllığı Çizelge 11 'de verilmiştir.

Çizelge 11. İşletmelerde belirlenen el emeği ücret karş1lı̆̆ (‡/da)

\begin{tabular}{lrcc}
\hline & \multicolumn{3}{c}{ Mal Sahibi İşletmeciliği } \\
\cline { 2 - 4 } & Sulu & Kuru & Ortalama \\
\hline El Emeği Ücret karşıllı̆ı (Eü) (†) & 131,62 & 47,54 & 87,69 \\
\hline Eü’ nün Gsh İçerisindeki Oranı (\%) & 21,08 & 15,62 & 18,70 \\
\hline
\end{tabular}

Mal sahibi tarafindan işletilen arazilerde belirlenen el emeği ücret karşıllı̆ı suluda 131,62 §/da, Gsh içindeki oranı \%21,08'dir. Kuruda bu rakam 47,54 £/da olup, Gsh içindeki oranı \%15,62'dir. Ortalama el emeği ücret karşılığı 18,70 Æ/da olarak hesaplanmış ve Gsh içindeki oranı ise \%18,70 olarak belirlenmiștir.

Araştırma bölgesinde toplam el emeği ücret karşıllğı suluda ortalama 81,31 €/da olup Gsh içindeki oranı $\% 14,47$ 'dir. Kuruda bu değer 28,78 €/da olup Gsh içindeki oranı $\% 14,51$ 'dir. El emeği ücret karşılığının ortalaması 53,26 ‡/da olup Gsh içindeki oranı ise \%18,70 olarak hesaplanmıştır.

\subsubsection{Vergiler $(\mathrm{V})$}

İşletmelere ait ortalama vergi masrafları Çizelge 12 'de verilmiştir.

Çizelge 12. İşletmelerde belirlenen ortalama vergi masrafları

\begin{tabular}{|c|c|c|}
\hline & $\begin{array}{ll}\text { Vergi Masrafları (V) } & (\mathbf{f} / \mathrm{da}) \\
\end{array}$ & Gsh İçerisindeki Oranı (\%) \\
\hline Mal Sahibi Sulu & 4,93 & 0,79 \\
\hline Mal Sahibi Kuru & 2,47 & 0,81 \\
\hline Ortalama & 3,65 & 0,78 \\
\hline Ortakçılık Sulu & 1,98 & 0,69 \\
\hline Ortakçılık Kuru & 1,28 & 0,78 \\
\hline Ortalama & 1,63 & 0,72 \\
\hline
\end{tabular}

Mal sahibi tarafından işletilen arazilerde belirlenen vergi masrafları suluda 4,93 £/da, Gsh içindeki oranı $\% 0,79$ 'dur. Kuruda bu rakam $2,47 € /$ da olup, Gsh içindeki oranı $\% 0,81$ 'dir. Ortalama vergi masrafı ise 3,65 ‡/da ve Gsh içindeki oranı $\% 0,78$ 'dir.

Ortakçılıkla işletilen arazilerde belirlenen vergi masrafları suluda 1,98 €/da, Gsh içindeki oranı $\% 0,69$ 'dur. Kuruda ise bu rakam 1,28 £/da olup, Gsh içindeki oranı da $\% 0,78$ 'dir. Ortalama vergi masrafi 1,63 £/da, Gsh içindeki oranı ise \%0,72'dir.

Araştırma bölgesinde toplam vergi masrafi suluda ortalama 3,52 £/da olup Gsh içindeki oranı $\% 0,76$ 'dır. Kuruda bu masraf 1,76 £/da olup Gsh içindeki oranı \%0,89'dur. Vergi masraflarının ortalaması 2,58 €/da olup Gsh içindeki oranı ise $\% 0,80$ olarak hesaplanmıştır.

\subsection{Arazi rantları (R)}

Kamulaştırma Kanunu'nda da, arazinin geliri için net gelir tanımı yer almaktadır. Arazinin net gelirini hesaplarken, arazide bölge koşullarına göre normal bir üretim sisteminin uygulandığı kabul edilmektedir. Normal üretim sistemi, arazinin bulunduğu bölgedeki yaygın olan üretim tekniğidir (Kılıç, 2011).

Araştırma kapsamındaki işletmelerin tarla arazilerinde belirlenen arazi rantları, gayrisafi hasıladan tüm masraf kalemleri çıkarılarak hesaplanmıştır. İncelenen mal sahibi, ortakçı ve kiracı işletmelerine ait arazi rantları Çizelge 13 'te verilmiştir.

32 | P a g e

www.iiste.org 
Çizelge 13. İşletmelere ait arazi rantları

\begin{tabular}{lccc}
\hline $\begin{array}{l}\text { Arazi Nev'i ve Tasarruf } \\
\text { Durumu }\end{array}$ & $\begin{array}{c}\text { Rant } \\
(\mathbf{f} / \mathbf{d a})\end{array}$ & $\begin{array}{c}\text { Rant'm Gsh İçindeki } \\
\text { Oranı (\%) }\end{array}$ & $\begin{array}{c}\text { Rant' In Kira İçindeki } \\
\text { Oranı (\%) }\end{array}$ \\
\hline Mal Sahibi Sulu & 196,01 & 31,39 & - \\
Mal Sahibi Kuru & 105,86 & 34,78 & - \\
Ortalama & $\mathbf{1 5 9 , 8 4}$ & $\mathbf{3 4 , 0 8}$ & - \\
\hline Ortakçı Sulu & 138,17 & 48,15 & - \\
Ortakçı Kuru & 65,29 & 39,72 & - \\
Ortalama & $\mathbf{1 0 2 , 0 4}$ & $\mathbf{4 5 , 1 8}$ & - \\
\hline Kiracı Sulu & 76,54 & - & 97,00 \\
Kiracı Kuru & 48,18 & - & 97,00 \\
Ortalama & $\mathbf{5 9 , 5 5}$ & - & $\mathbf{9 7 , 0 0}$ \\
\hline Sulu Ortalama & 165,03 & 35,45 & - \\
Kuru Ortalama & 87,02 & 43,88 & - \\
Genel Ortalama & $\mathbf{1 0 7 , 4 0}$ & $\mathbf{3 8 , 1 5}$ & - \\
\hline
\end{tabular}

Araştırma bölgesindeki araziler arasında en yüksek rant 196,01 €/da ile mal sahibi tarafından işletilen sulu tarla arazilerinde tespit edilmiştir. Bunu 138,17 £/da değeri ile ortakçıllkla işletilen sulu tarla arazileri takip etmiştir. En düşük rant ise 48,18 €/da değeri ile kiracılıkla işletilen kuru tarla arazilerinde belirlenmiştir.

İşletmeler genel olarak incelendiğinde, arazi rantının hem arazi nev'ine göre, hem de aynı arazi nevi içerisinde farklılık gösterdiği tespit edilmiştir. Arazilerde verim farklılığı yanında ulaşım kolaylığ 1 , kente yakın olma durumu, münavebenin kolaylıkla değiştirilebilmesi, tarla şeklinin düzgün olması, sulu ise sulama kolaylığı ve arazi büyüklüğü gibi gelir dışı etkenlerin de rantı etkilediği bilinmektedir. $\mathrm{Bu}$ faktörlerin olumlu olması masrafları azaltmakta, olumsuz olması ise artırmaktadır (Keskin, 1994).

\subsection{Arazilerin satış değerleri}

Pazar değerini ifade eden fiyatın arazi piyasasında oluşabilmesi için uzun bir alım satım dönemi gerekebilmektedir. Arazilerin diğer mal ve hizmetlerde olduğu gibi spot şekilde, yani malların anında satılabileceği bir pazar yapısı mevcut olmadığından ve likiditesinin az olması nedeniyle de diğer mal ve hizmetlerden farklılık gösterdiği bilinmektedir. Gelirlerin kapitalizasyonu yaklaşımıyla bir araziye değer biçme gelir odaklı olduğundan, gelecekte elde edilebilecek gelirlerin de dikkate alınması gerekliliği ortaya çıkmaktadır.

Arazi değerini etkileyen faktörler genellikle iki grup altında incelenmektedir (Birinci, 1993).

a) Fiziki (Doğal) Faktörler: Toprağın üretim kabiliyeti, arazinin topografik durumu, iklim durumu ve arazinin coğrafi mevkiidir.

b) Ekonomik ve Sosyal Faktörler: Nüfus miktarı ve artış hızı, tarımsal ürün fiyatları, arazi arz ve talebi, arazinin geliri, pazarlama olanakları, enflasyon, tarımsal kredilerin miktarı, türü ve faiz hadleri, arazi kirası, teknolojik gelişmeler, toplumun satın alma alışkanlıkları ve alım gücü, sosyal ve çevresel koşullardır.

Türkiye ekonomisinde enflasyon hızının yüksek düzeyde seyretmesi ve para değerindeki sürekli düşüş, bir yandan gayrimenkule olan talebi olağanüstü artırırken diğer yandan da, hızlı fiyat artışları arazi değerinin sürekli yükselmesine neden olmaktadır. Enflasyon hızının tarımsal arazi fiyatlarına etkisi, belirtilen yönüyle serbest piyasa koşulları olan bütün ülkelerde görülmektedir (Özçelik, 1983).

İncelenen tarla arazilerinde cari satı̧ fiyatları tespit edilirken öncelikle arazi sahipleri, bölgeyi iyi tanıyan kişiler, emlakçılar, çeşitli komisyoncular, Tapu ve Kadastro Müdürlüğü elemanlarıyla görüşülmüştür. Bu kişi ve kurumlardan alınan veriler ile sözlü beyanlar kullanılarak araştırmaya konu arazilerin cari satı̧s fiyatlarında düzeltmelere gidilmiş̧ir.

Yapılan araştırmalar neticesinde mal sahibi tarafindan işletilen sulu tarla arazilerinin cari satış değerleri $2.500,00$ €/da ile 5.500,00 €/da arasında değiş̧tiği belirlenmiştir. Ortalama değer ise 3.643,54 €/da olarak hesaplanmıştır. Mal sahibi tarafından işletilen kuru tarla arazilerinin cari satış değerlerinin ise 33 | P a g e www.iiste.org 


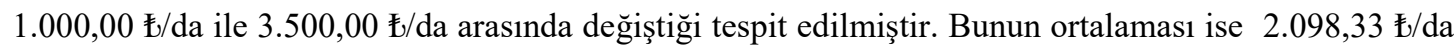
olarak belirlenmiştir. Mal sahibi tarafından işletilen tarla arazilerinin cari satış değerleri ortalaması ise 2.986,31 €/da olarak hesaplanmıştır.

Ortakçılıkla işletilen sulu tarla arazilerinin cari satış değerleri ise 2.500,00 €/da ile 6.000,00 છ/da arasında değişmektedir. Ortalaması 4.646,35 €/da olarak hesaplanmıştır. Kuru tarla arazilerinin cari satış değerlerinin ise $1.500,00$ 七/da ile 3.500,00 €/da arasında değiştiği ve ortalamasının 2.316,29 €/da olduğu belirlenmiştir. Ortakçılıkla işletilen tarla arazilerinin cari satış değerleri ortalaması da 3.297,38 Đ/da olarak tespit edilmiştir.

Kiracılıkla işletilen sulu tarla arazilerinin cari satı̧ değerleri 1.500,00 £/da ile 3.000,00 $\mathrm{f} / \mathrm{da}$ arasında değişmektedir. Ortalaması ise $1.677,08 \mathrm{€} / \mathrm{da}$ olarak hesaplanmıştır. Kuru tarla arazilerinin cari satış değerlerinin ise $1.000,00 € /$ da ile $2.000,00 € /$ da arasında değişmekte olduğu ve ortalamasının da $1.187,50$ Đ/da olduğu belirlenmiştir. Kiracılıkla işletilen tarla arazilerinin cari satış değerleri ortalaması ise $1.383,33 € /$ da olarak hesaplanmıștır.

Araştırma neticesinde ortaya çıkan sonuçlarla bu konuda yapılmış diğer çalışmalar (Birinci,1997; Aydın, 2007; Baştürk, 2011; Avcı ve Akay, 2012; İncir, 2015) karşılatırılmıştır. Bulunan değerler cari satış değerlerini bölge ve yıllara göre önemli ölçüde değişiklik gösterdiği tespit edilmiştir.

\section{SONUÇ ve ÖNERILER}

Arazilerin değerlerinin belirlenmesi aşamasında, kapitalizasyon oranına etki eden faktörlerin belirlenmesi önemli yer tutmaktadır. Bu araştırmada, Bayburt ili merkez ilçede kapitalizasyon oranına etki eden gelir ve masraf unsurları tespit edilmeye çalışılmıştır.

Buna göre münavebe sistemi olarak suluda hububat-yem bitkisi- hububat, kuruda hububat-yem bitkisinadas ve hububat-yem bitkisi-hububat- nadas şeklinde uygulama olduğu belirlenmiştir.

Mal sahibi tarafından işletilen arazilerin toplam gayrisafi hasıla değerlerine $€ /$ da bazında bakıldığında bu değer, suluda $624,40 € /$ da ve kuruda ise $304,36 £ /$ da olarak bulunmuştur. Dekara ortalama gayrisafi hasıla ise 468,95 € olarak hesaplanmıştır.

Araştırma bölgesinde ortakçılıkta, üretimle ilgili her türlü gelir ve giderlerin paylaşımı yarı yarıyadır. Ortakçılıkla işletilen sulu ve kuru tarım arazilerine ait toplam gayrisafi hasıla değerleri €/da bazında suluda $286,97 £ /$ da, kuruda $164,36 £ /$ da ve ortalama gayrisafi hasıla değeri ise $225,87 £ /$ da olarak hesaplanmiştır.

Kiracılıkla işletilen sulu ve kuru tarım arazilerine ait toplam gayrisafi hasıla değerleri suluda 28.170,87 £, kuruda 26.532,78 £ olarak hesaplanmıştır. Kiracılıkla işletilen sulu ve kuru tarım arazilerine ait

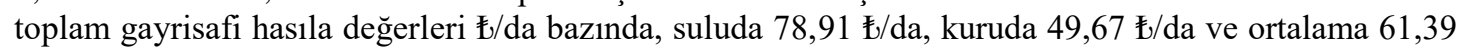
$€ /$ da olarak tespit edilmiştir.

Toplam gayrisafi hasıla değerlerinin $€ /$ da ortalaması suluda $465,47 € /$ da, kuruda ise $198,32 € /$ da olarak belirlenmiştir. Gayrisafi hasılanın genel ortalaması ise 322,83 €/da'dır.

Mal sahibi tarafından işletilen arazilere ait masraflar suluda 243,07 £/da olup Gsh içindeki oranı \%38,93'tür. Bu masraflar kuruda 121,43 £/da, Gsh içindeki oranı ise \%39,90’dır. Ortalama masraflar ise 179,84 €/da olup Gsh içindeki oranı \%38,35'tir.

Ortakçılık işletmelerinde belirlenen masraflar suluda 127,05£/da olup, Gsh içindeki oranı \%44,27’dir. Kuruda bu masraf 85,37 £/da olup Gsh içindeki oranı ise \%51,94’tür. Ortalama masraf 106,28 £/da olup, Gsh içindeki oranı \%47,05'tir.

Toplam masraf değerleri suluda ortalama 180,43 £/da olup Gsh içindeki oranı \%38,76'dır. Kuruda ise bu rakam 61,53 £/da olarak hesaplanmıştır. Gsh içindeki oranı ise \%31,03’tür. Toplam masrafların genel ortalaması 116,95 €/da olup, Gsh içindeki oranı ise \%36,23 olarak hesaplanmıştır.

Toplam müstecir sermayesi faiz karşılığ suluda ortalama 12,82 £/da olup Gsh içindeki oranı \%2,75’tir. Kuruda ise bu rakam 8,38 £/da olup Gsh içindeki oranı \%4,23’tür. Toplam müstecir sermayesi faiz karşılı̆̆ının ortalaması 10,33 £/da olup Gsh içindeki oranı \%3,20 olarak hesaplanmıştır.

Toplam el emeği ücret karşılığı suluda ortalama 81,31 £/da olup Gsh içindeki oranı \%14,47’dir. Kuruda bu değer 28,78 €/da olup Gsh içindeki oranı \%14,51'dir. El emeği ücret karşılığının ortalaması $53,26 £ /$ da olup Gsh içindeki oranı ise \%18,70 olarak hesaplanmıştır.

Toplam vergi masrafi suluda ortalama 3,52 £/da olup Gsh içindeki oranı \%0,76'dır. Kuruda bu masraf 1,76 £/da olup Gsh içindeki oranı \%0,89’dur. Vergi masraflarının ortalaması 2,58 £/da olup Gsh içindeki oranı ise \%0,80 olarak hesaplanmıştır.

Araziler arasında en yüksek rant 196,01 €/da ile mal sahibi tarafından işletilen sulu tarla arazilerinde tespit edilmiştir. Bunu 138,17 £/da değeri ile ortakçılıkla işletilen sulu tarla arazileri takip etmiştir. En düşük rant ise 48,18 €/da değeri ile kiracılıkla işletilen kuru tarla arazilerinde belirlenmiştir.

34 | P a g e

www.iiste.org 
Mal sahibi tarafından işletilen sulu tarla arazilerinin cari satış değerleri 2.500,00 £/da ile 5.500,00 ‡/da arasında değiştiği belirlenmiştir. Ortalama değer ise 3.643,54 $\mathrm{f} / \mathrm{da}$ olarak hesaplanmıştır. Mal sahibi tarafından işletilen kuru tarla arazilerinin cari satış değerlerinin ise 1.000,00 ‡/da ile 3.500,00 ‡/da arasında değiştiği tespit edilmiştir. Bunun ortalaması ise 2.098,33 €/da olarak belirlenmiştir. Mal sahibi tarafindan işletilen tarla arazilerinin cari satış değerleri ortalaması ise 2.986,31 €/da olarak hesaplanmıştır.

Ortakçıllıkla işletilen sulu tarla arazilerinin cari satış değerleri ise $2.500,00$ ‡/da ile $6.000,00$ ‡/da arasında değişmektedir. Ortalaması $4.646,35$ €/da olarak hesaplanmıştır. Kuru tarla arazilerinin cari

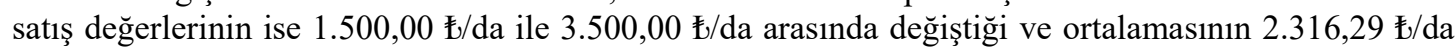
olduğu belirlenmiştir. Ortakçılıkla işletilen tarla arazilerinin cari satış değerleri ortalaması da 3.297,38 €/da olarak tespit edilmiştir.

Kiracılıkla işletilen sulu tarla arazilerinin cari satış değerleri 1.500,00 ‡/da ile 3.000,00 £/da arasında değişmektedir. Ortalaması ise $1.677,08 \mathrm{\ddagger} / \mathrm{da}$ olarak hesaplanmıştır. Kuru tarla arazilerinin cari satış değerlerinin ise $1.000,00 € /$ da ile $2.000,00 € /$ da arasında değişmekte olduğu ve ortalamasının da $1.187,50$ €/da olduğu belirlenmiş̧tir. Kiracılıkla işletilen tarla arazilerinin cari satış değerleri ortalaması ise $1.383,33$ €/da olarak hesaplanmıştır.

Araştırmada tespit edilen değerler genellikle ortalama değerlerdir. Bundan sonra aynı bölgede bir kamulaştırma yapılırsa bu araştırma bir yardımcı kaynak olarak kullanılabilir. Kamulaştırmanın yapılacağı dönem ile bu araştırmanın yapıldığı dönem arasında yörede üretim deseninin değişmesi olasılık dâhilindedir. Ayrıca arazinin kıymeti üretim desenin değişmesinden daha başka etkenlere de bağlıdır. Bunlar dikkate alınarak bu ortalama değerler güncellenmeli, güncellenme yeterli değil ise yeniden bir araştırma yapılmalıdır.

Araştırma bölgesinde kayıt tutulmaması nedeniyle, üreticilere sorulan sorularda ne kadar tekrarlamalı sorulara çokça yer verilse de üreticiler hafızalarına dayandırdıkları bilgiler vermeleri neticesinde bazı sıkıntılar olmaktadır. Bölge çiftçileri üretim döneminde gelirlerini ve giderlerini ya yazmakta fakat düzenli olmadığı için kendisi ve araştırmacılar için güvenilir bir kaynak olmamakta ya da hiç kayıt tutmamaktadırlar. Bilinçli olarak kayıt tutmaları teşvik edilmelidir.

Arazinin değerine etki eden olumlu ve olumsuz faktörlerin dikkate alınarak değeri biçilmek istenen araziye uydurulması gerekmektedir. Bunun için alan araştırmaları yapılmalıdır. Aynı bölgede hatta aynı il/ilçe içerisinde farklı arazi nev'ileri ve farklı işletme biçimlerine göre değiş̧ik kapitalizasyon oranları tespit edilebilmektedir. Örneğin Arazinin dere kenarında olması çoğu zaman olumlu bir faktör olarak değere etki etmekte iken aynı zamanda su basmalarına karşı bir tehdidin olması dolayısıyla olumsuz bir etki de gösterebilmektedir. Değer biçme uzmanının bu iki yönü de değerlendirmesi gerekmektedir. Ülke genelinde bu tür araştırmaların artırılması ile arazilerin gelir-gider durumları ve değerleri tespit edilmelidir. Bu hem iyi bir kaynak hem de uygulanabilir bir tarım politikasının hayata geçmesine faydalı olabilir.

\section{KAYNAKLAR}

Açıl, A.F. 1977. Tarımsal Urun Maliyetlerinin Hesaplanması Ve Memleketimiz Tarımsal Urun Maliyetlerindeki Gelişmeler. Ankara Üniversitesi Ziraat Fakültesi Yayınlan: 665, Ankara.

Akay, M., 1996. Tokat İli Niksar Ovası Tarım İşletmelerinin Yapısal Analizi, İşletme Sonuçlarını Etkileyen Faktörlerin Değerlendirilmesi ve Doğrusal Programlama Yöntemiyle Planlanması Üzerine Bir Araştırma. Yayımlanmamış Doktora Tezi. Gazi Osman Pasa Üniversitesi Tokat.

Aktaş, A. R., 2000. Tokat İli Niksar Ovası Tarla Arazilerinde Kapitalizasyon Oranının Saptanması Üzerine Bir Araştırma. Yayımlanmamış Yüksek Lisans Tezi. Gazi Osman Paşa Üniversitesi, Tokat

Anonim, 2002. Tarım Arazilerinin Kamulaştırma Bedellerinin Takdirinde Kullanılabilecek Kapitalizasyon Oranları ve Arazi Net Gelirlerinin Tespitine İlişkin Mühendislik Hizmetleri Araştırması Sinop-Boyabat Devlet Yolu Güzergâhı İle İlgili Rapor. Ankara: Eduser Eğitim Danışmanlık ve Uzmanlık Hizmetleri Limited Şirketi, Ankara

Aslan, İ. 2002. Tokat İli Artova İlçesi Tarla Arazilerinde Kapitalizasyon Oranının Tespiti Üzerine Bir Araştırma. Yüksek Lisans Tezi, Gaziosmanpaşa Üniversitesi, Tokat.

35 | P a g e

www.iiste.org 
Avcı, İ. ve Akay, M. 2012. Tokat ili pazar ilçesi tarla arazilerinde kapitalizasyon oranının tespiti, Gazi Osmanpaşa Üniversitesi Ziraat Fakültesi Dergisi, 29(1):65-74.

Aydın, H. 2007. Zile Ovası Tarla Arazilerinde Kapitalizasyon Oranının Tespiti Üzerine Bir Araştırma. Yüksek Lisans Tezi, Gaziosmanpaşa Üniversitesi, Tokat.

Aydın, H. ve Akay, M. 2008. Zile Ovası Tarla Arazilerinde Kapitalizasyon Oranının Tespiti Üzerine Bir Araştırma, Gazi Osmanpaşa Üniversitesi Ziraat Fakültesi Dergisi, 25(1);23-31.

Baştürk, A. 2011. Samsun İli Ladik İlçesi Tarla Arazilerinde Kapitalizasyon Oranının Saptanması Üzerine Bir Çalışma. Yüksek Lisans Tezi, Gaziosmanpaşa Üniversitesi, Tokat.

Birinci, A. 1993. Türkiye'de Gayrimenkul (Tarla Arazisi ve Arsa) Kıymetlerindeki Değişme ve Gelişmeler ve $\mathrm{Bu}$ Değişime Etki Eden Faktörler. Yüksek Lisans Tezi. Atatürk Üniversitesi, Erzurum.

Birinci, A. 1997. Erzurum ve Erzincan İllerinde Tarla Arazilerinde Kapitalizasyon Oranının Saptanması Üzerine Bir Araştırma. Atatürk Üniversitesi Fen Bilimleri Enstitüsü Tarım Ekonomisi Anabilim Dalı, Doktora Tezi (Yayımlanmamış), Erzurum.

Çiçek, A. ve Erkan, O. 1996. Tarım Ekonomisinde Araştırma ve Örnekleme Yöntemleri. Gazi Osman Pasa Üniversitesi Ziraat Fakültesi Yayını, Tokat.

Engindeniz, S.,Yercan, M., ve Adanacıŏlu, H. 2009. Gördes Barajı Göl Alanında Kalan Tarım Arazilerinin Kamulaştırılmasında Kullanılabilecek Arazi Gelirlerinin, Kapitalizasyon Oranlarının ve Birim Arazi Değerlerinin Saptanması Üzerine Bir Araştırma, Yediveren Matbaac1lık, İzmir, s.95.

Gülten, Ş. 1975. Kıymet Takdiri. Atatürk Üniversitesi Ziraat Fakültesi, Ankara.

Hayran, S., 2013. Türkiye'de Tarım Kesiminin Vergilendirilmesi. Iğdır Üniversitesi Fen Bilimleri Dergisi 3(1), 69-72.

İncir, S. 2015. Tokat İli Çevreli Beldesi Tarla Arazilerinde Kapitalizasyon Oranının Saptanması Üzerine Bir Araştırma. Yüksek Lisans Tezi, Gaziosmanpaşa Üniversitesi, Tokat.

Karagolge, C., 1996. Tarımsal İşletmecilik, Atatürk Üniversitesi Yayı No.824, Ziraat Fakültesi Yayın No.326, Ders Kitap Serisi, No.74, Erzurum.

Keskin, G. 1994. Eskişehir İli Tarla Arazilerinde Ortalama Kapitalizasyon Oranının Bulunması. Yüksek Lisans Tezi. Ankara Üniversitesi, Ankara.

Kılıç, O. 2011. Tarım arazisi için kapitalizasyon oranının hesaplanması. Anadolu Tarım Bilimleri Dergisi, 26(2), 181-187.

Murray, W.G 1969. Farm Appraisal and Valuation. lowa State University Press, Ames, lowa.

Mülayim, Z.G. 2008. Tarımsal değer biçme (genel-özel-yasal), Yetkin Yayınları, Ankara, s.358.

Mülayim, Z.G. 1994. Tarımsal Değer Biçme (Genel-Özel-Yasal). Yetkin Yayınları, Ankara.

Mülayim, Z.G. 2001. Tarımsal Değer Biçme ve Bilirkişilik, Yetkin Yayınları, Ankara, s.361.

Mülayim, Z.G., Erkuş, A. ve Vural, H. 1986. Atatürk ve Karakaya Barajları Gol Alanlarında Kalan Taşınmazların Değer Takdirinde Uygulanabilecek Kapitalizasyon Oranının Tespiti Üzerine Bir Araştırma. DSİ, Ankara.

36 | P a g e

www.iiste.org 
Ökmen, M., ve Yurtsever, H., 2010. Kentsel planlama sürecinde oluşan kamusal rantın vergilendirilmesi, Maliye Dergisi, 158,58-74.

Özçelik, A. 1983. Kıymet Takdirinde Kullanılan Bazı Faktörlerin Çubuk Ovası Tarla Arazilerinde Saptanmasi. Yüksek Lisans Tezi, Ankara Üniversitesi, Ankara.

Tanrıvermiş, H. 1996, Sanayinin Neden Olduğu Çevre Kirliliğinin Tarıma Verdiği Zararların Değerinin Biçilmesi: Samsun Gübre Ve Karadeniz Bakır Sanayileri Örneği. Yüksek Lisans Tezi, Ankara Üniversitesi, Ankara.

Taraklı, D. 1979. Mudurnu İlçesi Orman Köyleri Tarım işletmelerinin Ekonomik Analizi ve İlçe İçin Doğrusal programlama Yöntemi ile Optimum İşletme Planlarının Saptanması, ODTÜ Mimarlık Fakültesi Şehir ve Bölge Planlama Bölümü, Ankara.

Vural, H. 1987. Tarımsal Kıymet Takdirlerinde Kapitalizasyon Oranının Saptanması Üzerine Bir Araştırma. Doktora Tezi, Ankara Üniversitesi, Ankara. 